\title{
A Comparison of the Effectiveness of Two Stay-Two Stray and Pair Checks Cooperative Learning Models Towards Primary School Mathematics Learning Outcomes
}

\author{
I Nyoman Laba Jayanta ${ }^{1 *}$, Gusti Ngurah Sastra Agustika ${ }^{1}$ \\ ${ }^{1}$ Elementary Teaching Education, Universitas Pendidikan Ganesha, Indonesia \\ *Corresponding author. Email: laba.jayanta@undiksha.ac.id
}

\begin{abstract}
This research is an experimental study that aims to compare the effectiveness of the Two Stay-Two Stray and Pair Checks cooperative learning models on Mathematics learning outcomes. This study uses a quasi-experimental approach with a non-equivalent control group design. This design uses 3 groups, each of which is given different treatment, namely a cooperative model of the Pair Checks type, the Two Stay-Two Stray type and a conventional learning model. The determination of the treatment for each group was done with a random method. Each group's mathematical mastery was measured twice, that is before given a pre-test and after given a post-test. The result of the effectiveness of the cooperative model of Pair Checks type and Two Stay-Two Stray was calculated by using the coefficient of effectiveness of Cohen's D. The result of the effectiveness coefficient of the Pair Checks cooperative model is $d=0.23$ and the effectiveness coefficient of the Two Stay-Two Stray cooperative model is $\mathrm{d}=0.48$ with a moderate influence category, which means the cooperative type of Two Stay-Two Stray model has better influence
\end{abstract}

Keywords: Effectiveness, Cooperative Model, Mathematics, Elementary School

\section{INTRODUCTION}

The development and progress of a nation are largely determined by the quality of education received by its people. Through education, people obtain various knowledge and information for their lives. Therefore, education becomes a vital need, so that all components related to the quality of education must be planned and implemented properly.

One of the components of the quality of education is the learning process that occurs in classrooms. To provide a meaningful learning experience, a learning model that is appropriate to the characteristics of the learning material is required. One of the learning materials provided in elementary schools is Mathematics. Mathematics has an essential role in various aspects of life. Many problems and activities in life must be solved with Mathematics, such as measuring, weighing, calculating, and so forth [1].

Considering the crucial role of mathematics, it is supposed to make students enjoy mathematics, but until now, many students still consider mathematics as one of the subjects that is difficult to understand. This phenomenon is based on the data obtained from the UPT Department of Sports, Youth and Education in South Denpasar district. It was found that the average Mathematics score of students in the 2018 national exam was 65.55 with category C. This result is lower than the average scores of other subjects such as Natural Sciences and Indonesian Language with the score of category B. The low learning outcomes are due to several factors, one of which is the selection of learning models that were not in accordance with the characteristics of the learning material.

Based on these problems, it is necessary to find out the learning model that is suitable for the characteristics of Mathematics material in elementary schools. The results of the study conducted by Supriatna [2] with the subject of VII grade junior high school students showed that the classes taught with Pair Checks type had an increase with high interpretations. Then, the classes taught with Problem-based Learning had an increase with moderate interpretations. From these results, the Pair 
Checks model is a good model to be applied to Mathematics material for junior high school students. In contrast to the study conducted by Prakoso [3], which found that Social Science learning materials with the Pair Checks learning model gave unfavourable results compared to the Numbered - Heads Together learning model. Furthermore, a study carried out by Apriandi [4] found that learning with the Two Stay-Two Stray cooperative learning model provides the same mathematics learning achievement as using Numbered Heads Together type of cooperative learning.

Based on the findings of several studies that have been conducted, the Pair Checks type of cooperative learning model and the Two Stay-Two Stray type are alternative learning models that can be used in Mathematics learning for junior high school students. However, in those studies, it is not yet known how much the effectiveness of the learning models on Mathematics learning material is. In this study, an experiment will be conducted with the subject of elementary school students by using the Pair Checks and Two Stay-Two Stray cooperative learning models to find out how effective each model is.

Pair Checks and Two Stay-Two Stray learning models are included in cooperative learning popularized by Spencer Kagan. Pair Checks is a group learning model between two people or in pairs. This model applies cooperative learning that requires independence and the ability of students to solve problems [5]. Meanwhile, the Pair Checks model is a learning model where students pair up with each other and solve the given problems. This learning model also functions to train students' social sense, cooperation, and the ability to give assessments [6]. This model aims to improve the ability of students to express their ideas, thoughts and opinions. The same argument also shows that the Pair Checks model is a learning process that emphasizes group cooperation [7], where each group member must have independence and the ability to solve the given problems. Meanwhile, the Two Stay-Two Stray model is a group learning system, whose aim is that students can work together, be responsible, help each other solve problems, and encourage each other to make an achievement [5]

\section{METHOD}

This research was conducted in the second semester of the 2018/ 2019 academic year. This study is a quasiexperimental study with a non-equivalent control group design that is modified for 3 groups. The population of this research is the fourth-grade students of SDN Gugus Moh. Hatta in the academic year of 2018/2019, with 244 students. The determination of the research groups taught with the Pair Checks and the Two Stay-Two Stray models was done with a random technique. The selected elementary school as the control group is grade IV SDN 4 Panjer which amounts to 43 students, the elementary school selected as the experimental group with Pair Checks learning model is grade IV SDN 2 Panjer totalling 39 students and the elementary school chosen as the experimental group with the Two Stay-Two Stray learning model is grade IV SDN 6 Panjer with 41 students. The data was collected using a common test method comprising ordinary multiple-choice questions. The experimental group and the control group were given a pre-test to measure the competence of mathematical knowledge before given the treatment of the learning model, then continued with the treatment given in 6 meetings, and after given the treatment, all groups were given a post-test. Pre-test and Post-test data were then analysed to look for increasing scores after given the treatment that was obtained from calculating the gain score. The measurement of the effectiveness of the learning models was done by using the effectiveness coefficient of Cohen's D by comparing each of the experimental groups with the control group. Calculating the effectiveness coefficient of Cohen's D was firstly calculated using an independent sample t-test. Because the number of students in each group is more than 30 students, according to the central limit theorem the gain score data can be analysed without a normality test.

\section{RESULTS AND DISCUSSION}

The effectiveness of the Pair checks and Two StayTwo Stray learning models was done by analyzing the gain score data. The use of gain score is done to overcome the problem of the unequal mean score from the results of the pre-test. Based on the test result using analysis of variance on the gain score data, the results are as follows:

Table 1. Summary

\begin{tabular}{|l|l|l|l|l|}
\hline \multicolumn{1}{|c|}{ Groups } & $\begin{array}{c}\text { Coun } \\
\mathrm{t}\end{array}$ & Sum & Average & Variance \\
\hline Pair Checks & 39 & 3064 & 78.5641 & 358.305 \\
\hline $\begin{array}{l}\text { Two Stay- } \\
\text { Two Stray }\end{array}$ & 41 & 2564 & 62.53659 & 523.8049 \\
\hline $\begin{array}{l}\text { Conventi- } \\
\text { onal }\end{array}$ & 43 & 3088 & 71.81395 & 462.4408 \\
\hline
\end{tabular}


Table 2. ANOVA

\begin{tabular}{|l|c|c|c|c|c|c|}
\hline $\begin{array}{c}\text { Source } \\
\text { of } \\
\text { Varia- } \\
\text { tion }\end{array}$ & SS & df & MS & F & $\begin{array}{c}\text { P- } \\
\text { value }\end{array}$ & $\begin{array}{l}F \\
\text { crit }\end{array}$ \\
\hline $\begin{array}{l}\text { Between } \\
\text { Groups }\end{array}$ & $\begin{array}{c}5194 . \\
35\end{array}$ & 2 & 2597.18 & 5.77 & 0.00 & 3.07 \\
\hline $\begin{array}{l}\text { Within } \\
\text { Groups }\end{array}$ & $\begin{array}{c}5399 \\
0.30\end{array}$ & 120 & 449.92 & & & \\
\hline Total & $\begin{array}{c}5918 \\
4.65\end{array}$ & 122 & & & & \\
\hline
\end{tabular}

Based on the Anova table, it is known that the calculated $\mathrm{F}$ value $=5.772542$ is greater than the $\mathrm{F}$ table $=3.071779$, which means that there are differences in the mean pre-test scores of the groups taught using the Pair Checks, Two Stay-Two Stray and Conventional models. Therefore, to determine the effectiveness of the influence of the models, gain score data were used to overcome the inequalities in students' initial abilities. Because the data analysed in the form of the gain score, below is presented a summary of the gain score data for each group.

\subsection{A Description of Groups' Gain Score Data with Pair Checks Learning}

A description of gain score data is presented in the form of a table as follows:

Table 3. Statistic Measurement

\begin{tabular}{|c|c|}
\hline Mean & 15.79487179 \\
\hline Median & 12 \\
\hline Mode & 4 \\
\hline Standard Deviation & 14.12571281 \\
\hline Sample Variance & 199.5357625 \\
\hline Kurtosis & -0.144571049 \\
\hline Skewness & 0.993197813 \\
\hline Range & 48 \\
\hline Minimum & 0 \\
\hline Maximum & 48 \\
\hline Sum & 616 \\
\hline Count & 39 \\
\hline
\end{tabular}

Based on the table, it is known that the average gain score of the group of students, who were taught using the Pair Checks models is 15.79 meaning that the gain score data are centred around the value of 15 , with a skewness size of 0.99 also known that the distribution of the data has a positive slope or a right sloping. It means that most of the data have a fairly low data distribution, but there are some data with high gain scores so that the average is high. For the visualization of the distribution, a stem and leaf table is presented as follows:

Table 4. Steam and Leaf Diagram

\begin{tabular}{|c|l|}
\hline Stem & \multicolumn{1}{|c|}{ Leaf } \\
\hline 0 & 000044444448888888 \\
\hline 1 & 22222266 \\
\hline 2 & 000488 \\
\hline 3 & 26 \\
\hline 4 & 04448 \\
\hline
\end{tabular}

With the graphical display, it is clear that most students get a low gain score.

\subsection{A Description of Groups' Gain Score Data with Two Stay-Two Stray Learning}

A description of gain score data is presented in the form of a table as follows:

Table 5. Statistic Measurement

\begin{tabular}{|l|l|}
\hline Mean & 19.60976 \\
\hline Median & 16 \\
\hline Mode & 8 \\
\hline Standard Deviation & 13.87962 \\
\hline Sample Variance & 192.6439 \\
\hline Kurtosis & -1.20927 \\
\hline Skewness & 0.293779 \\
\hline Range & 44 \\
\hline Minimum & 0 \\
\hline Maximum & 44 \\
\hline Sum & 804 \\
\hline Count & 41 \\
\hline
\end{tabular}

Based on the table, it is known that the average gain score of the group of students, who learned with the Two Stay-Two Stray model is 19.6, meaning that the gain score is centred around the value of 19 , with a skewness size of 0.2. It is also known that the data distribution has a positive slope or right sloping, which means that most of the data has a fairly low data distribution, but with skewness size approaching 0 , the distribution is at a value of 19 . For the visualization of the distribution, a stem and leaf table is presented as follows: 
Table 6. Steam and Leaf Diagram

\begin{tabular}{|c|l|}
\hline Stem & \multicolumn{1}{|c|}{ Leaf } \\
\hline 0 & 00044444888888 \\
\hline 1 & 2222666 \\
\hline 2 & 00444488 \\
\hline 3 & 2222666 \\
\hline 4 & 00444 \\
\hline
\end{tabular}

With the graphical display, it can be seen that some students obtain low gain scores, but most of them are in the concentration of data, which is 19 .

\subsection{A Description of Groups' Gain Score Data with Conventional Learning}

A description of gain score data is presented in the form of a table as follows:

Table 7. Statistic Measurement

\begin{tabular}{|l|l|}
\hline Mean & 12.18605 \\
\hline Median & 8 \\
\hline Mode & 0 \\
\hline Standard Deviation & 16.74352 \\
\hline Sample Variance & 280.3455 \\
\hline Kurtosis & 7.443017 \\
\hline Skewness & 2.406866 \\
\hline Range & 88 \\
\hline Minimum & -4 \\
\hline Maximum & 84 \\
\hline Sum & 524 \\
\hline Count & 43 \\
\hline
\end{tabular}

Based on the table, it is known that the average gain score of a group of students, who were taught with conventional models is 12.1 meaning that the gain score is centred around the value of 12 , with a skewness size of 2.4. It is also known that the data distribution has a positive slope or right sloping, which means that most of the data has a very low data distribution. From the table, it is also known in the group that received a conventional learning model, there are students, who have a negative score gain, meaning that the obtained post-test scores are lower than the pre-test scores.

\subsection{Calculating the Effectiveness of Pair Checks and Two Stay-Two Stray Learning Models}

The effectiveness of the Pair Checks learning model was calculated after t-test by comparing the average experimental group taught with the Pair Checks model with the control group taught with the conventional learning model. T-test analysis results obtained as in the following table:

Table 8. t-test: Two-Sample Assuming Unequal Variances

\begin{tabular}{|l|l|l|}
\hline & Pair Checks & Conventional \\
\hline Mean & 15.79487 & 12.18605 \\
\hline Variance & 199.5358 & 280.3455 \\
\hline Observations & 39 & 43 \\
\hline $\begin{array}{l}\text { Hypothesized } \\
\text { Mean Difference }\end{array}$ & 0 & \\
\hline df & 80 & \\
\hline t Stat & 1.057949 & \\
\hline$P(T<=t)$ one-tail & 0.146631 & \\
\hline$t$ Critical one-tail & 1.664125 & \\
\hline$P(T<=t)$ two-tail & 0.293263 & \\
\hline$t$ Critical two-tail & 1.990063 & \\
\hline
\end{tabular}

Based on the results of the t-test analysis table, the value of $\mathrm{t}$ arithmetic $=1.057949<\mathrm{t}$ table $=1.990063$ with alpha $=5 \%$. It can be concluded that there is no difference in the improvement of students' mastery of mathematical knowledge taught with the Pair Checks and conventional learning models. Furthermore, the t-test results of a group of students, who was taught with the Two Stay-Two Stray model with a group of students, who was taught with conventional learning models are as follows:

Table 9. t-test: Two-Sample Assuming Unequal Variances

\begin{tabular}{|l|l|l|}
\hline Mean & $\begin{array}{c}\text { Two Stay- } \\
\text { Two Stray }\end{array}$ & Conventional \\
\hline Variance & 19.60976 & 12.18605 \\
\hline Observations & 192.6439 & 280.3455 \\
\hline $\begin{array}{l}\text { Hypothesized } \\
\text { Mean Difference }\end{array}$ & 0 & 43 \\
\hline df & 80 & \\
\hline t Stat & 2.216448 & \\
\hline$P(T<=t)$ one-tail & 0.01475 & \\
\hline$t$ Critical one-tail & 1.664125 & \\
\hline$P(T<=t)$ two-tail & 0.029501 & \\
\hline$t$ Critical two-tail & 1.990063 & \\
\hline
\end{tabular}

Based on the results of the t-test analysis table, the value of $\mathrm{t}$ arithmetic $=12.216448<\mathrm{t}$ table $=1.990063$ with alpha $=5 \%$. It can be concluded that there is a difference in the improvement of students' mastery of mathematical knowledge taught with the Two Stay-Two 
Stray and conventional learning models. Because there are significant differences in the improvement of students' mathematical knowledge before and after the implementation of the Two Stay-Two Stray learning model, the calculations were continued to find out the effectiveness coefficient. By using Cohen's D coefficient, the results of the effectiveness coefficient are presented as in the following table:

Table 10. Interpretation of Cohen's D Coefficient

\begin{tabular}{|l|l|l|}
\hline & \multicolumn{1}{|c|}{$\begin{array}{c}\text { Effectiveness } \\
\text { Coefficient }\end{array}$} & Category \\
\hline Pair Checks & 0.232003 & Medium \\
\hline $\begin{array}{l}\text { Two Stay-Two } \\
\text { Stray }\end{array}$ & 0.481649 & Medium \\
\hline
\end{tabular}

From the calculation of the results, it is obtained that the effectiveness coefficient of the Two Stay-Two Stray learning model is greater than the effectiveness coefficient of the Pair Checks learning model with a category of medium influence.

Based on the field observation, when the treatment process was given to the elementary school students, the Pair Checks learning model is less effective to be applied in primary schools. It is because not all elementary school students had the ability to express opinions or provide information to their friends properly. In the Pair Checks learning model, students' understanding depended on the ability of the group in problem solving, as a result, students were less well-informed from other groups, who had better abilities. In contrast to learning with the Two Stay-Two Stray learning model, the students could actively exchange information with other groups, who had better knowledge.

\section{CONCLUSION}

Based on the results of data analysis, it can be concluded that 1) there are no differences in students' learning outcomes taught with Pair Checks and conventional learning models 2 ) there are differences in students' learning outcomes that were taught with the Two Stay-Two Stray and conventional learning models, and 3) Two Stay-Two Stray learning model has better effectiveness than the Pair Checks learning model to be applied to students in grade IV of elementary school

\section{REFERENCES}

[1] A. Susanto, Teori Belajar Pembelajaran di Sekolah Dasar, Jakarta: Kencana Prenada Media Group, 2013.

[2] R. Supriatna, E. A. Afriansyah, Kemampuan Pemahaman Matematis Peserta Didik Melalui Cooperative Learning Tipe Pair Checks VS Problem
Based Learning, J. Pendidik. Mat. Indones. 3(1) (2018) 1-6.

[3] G. A. Prakoso, Keefektifan Model Pembelajaran Pair Check Dan Numbered-Heads Together (NHT) Ditinjau Dari Hasil Belajar Dalam Pembelajaran IPS Kelas 4 SDN Gugus Mahesa Jenar Ambarawa, Sch. J. Pendidik. dan Kebud. 5(3) (2015) 100-115.

[4] D. Apriandi, Efektivitas Model Pembelajaran Kooperatif Tipe Two Stay-Two Stray (Ts-Ts) dan Numbered Heads Together (NHT) Terhadap Prestasi Belajar Matematika Siswa Kelas VIII SMP Di Kabupaten Bantul Ditinjau Dari Aktivitas Belajar, JIPM (Jurnal Ilm. Pendidik. Mat.) 1(1) (2012) 1-15.

[5] M. Huda, Model-Model Pengajaran dan Pembelajaran: Isu-Isu Metodis dan Paragdimatis, Yogyakarta: Pustaka Belajar, 2013.

[6] A. Shoimin, 68 Model Pembelajaran Inovatif dalam Kurikulum 2013, Yogyakarta: Ar-Ruzz Media, 2014.

[7] Kurniasih and Sani, Ragam Pengembangan Model Pembelajaran: Untuk Peningkatan Profesionalitas Guru, Jakarta: Kata Pena, 2017. 